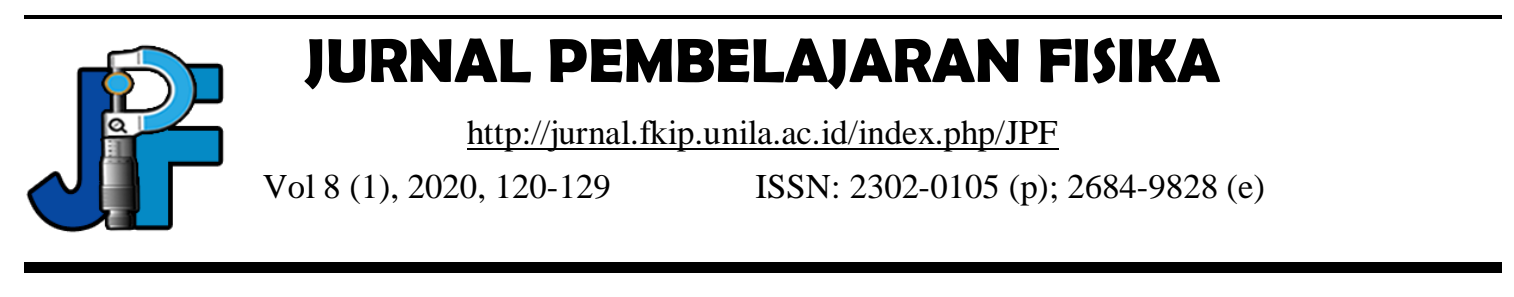

\title{
Feasibility Analysis of Teaching Materials with Pirolysis Tool in SMA Lubuklinggau City
}

\author{
Endang Lovisia *, Wahyu Arini \\ Departement of Physics Education STKIP PGRI Lubuklinggau, Indonesia \\ *e-mail:lovisiae@gmail.com
}

Received: April 25, 2020

Accepted: May 29, 2020

Published: June 29, 2020

\begin{abstract}
This research purpose to develop physics modules based on the subject of temperature and heat in class X students of Lubuklinggau State High School, and produce valid physics modules. The development of this research uses the ADDIE model with five stages namely analysis, design, development, implementation, and evaluation. Module validity was obtained from the results of expert validators namely material experts with a percentage of $82.23 \%$, media experts with a percentage of $81.94 \%$, and linguists with a percentage of $77.31 \%$ with a very good category. The conclusion obtained is the physics module of temperature and color. In terms of the experts, the material is valid with very good criteria, the linguist is categorized as valid with very good criteria and the media experts are valid with very good criteria.
\end{abstract}

Keywords: Feasibility, Teaching materials, Physics module

DOI: http://dx.doi.org/10.23960/jpf.v8.n1.202011 


\section{INTRODUCTION}

According to Law number 20 of 2003, a set of plans and several arrangements that contain objectives, content, and learning materials as well as ways that can be used as guidelines in organizing learning activities to achieve certain educational goals are called the curriculum. In the curriculum there is a priority for a better change to improve the quality of education, the latest curriculum is currently the 2013 curriculum. 2013 curriculum is currently a curriculum that emphasizes the activeness and independence of students in the learning process.

Permendikbud number 69 of 2013 concerning the basic framework and structure of the SMA / MA curriculum states that learning in the 2013 curriculum is designed to be active learning, where students actively find out and are strengthened by the use of learning models through a scientific approach. The scientific approach in learning includes the components of observing, asking, trying, processing, presenting, concluding, and creating. This approach is intended to provide students with an understanding that the information they get does not only come from the teacher. Therefore, the expected conditions of learning in the classroom are not teacher-centered but rather student-centered (Setiani, E., Feriansyah S)

The 2013 curriculum implementation which is based on character and competence must involve all components, including the components that exist in the education system itself. Changes in curriculum demanded to put forward characterbased education that aims to build the character of the nation's children (Morelent, Y). Meanwhile, according to (Suwarni) the 2013 competency-based curriculum focuses on acquiring certain competencies by students, one of the characteristics of the 2013 competency-based curriculum is that it utilizes the overall learning resources. The teacher competencies that must be possessed to achieve the success competencies of students by developing textbooks.

One branch of science that studies about the development of advanced technology and the concept of living in harmony with nature is physics. Physics learning is learning that not only studies theory but emphasizes the principles of scientific thinking. Therefore, most natural events are studied in physics. This causes the necessary activities and careful mindset of the teacher or students in learning physics. So physics does not only contain formulas that need to be memorized, but there is a need for concepts to be instilled in students through the active involvement of students in class.

Learning resources are one important component in learning. Learning resources used are not only limited to teachers in classrooms and school libraries. However, learning resources have evolved into cyberspace which can be accessed through the internet network. Learning resources used must be adjusted to the characteristics of students, learning objectives, media benefits, and media procurement. Learning resources used in learning can be printed and non-printed (Santi, N.W., Agus.S)

According to (Suwarni) defining textbooks is one of the books that becomes a reference for students' learning activities. Furthermore (Suwarni) said that textbooks are a set of subject matter materials that are arranged systematically displaying the integrity of the competencies that are mastered by students in learning activities. Textbooks are an important component in implementing learning because through textbooks, educators 
and students are easier to implement learning. Therefore, the textbook is an important part in the implementation of learning because it can be used both by teachers and students, to improve learning. All forms of materials used to assist teachers / instructors in carrying out teaching and learning activities are called teaching materials (Majid). According to (Prastowo) in general teaching material is a teaching material produced by an author or comes from a team of authors in which the preparation is based on the curriculum or interpretation of the applicable curriculum.

In line with this understanding, according to Nasution (Prastowo) in general teaching material is a teaching material produced by an author or comes from a team of authors where the preparation is based on the curriculum or interpretation of the applicable curriculum. With the textbooks, the teacher does not present too much learning material, so the teacher will spend more time guiding student learning. For students, the presence of textbooks will make students more independent in learning.

Textbooks in the teaching and learning process are needed. Textbooks needed are textbooks that can support the process of teaching and learning activities. Based on the above problems, it is considered necessary to conduct research with the title "Feasibility Analysis of Teaching Materials with Pyrolysis Tools on Temperature and Heat Material in Lubuklinggau City High School".

\section{METHOD}

\section{Research Design \& Procedures}

This type of research is included in development research. According to (Sugiyono) the research method used to produce a particular product, and to test the effectiveness of the product is called the research and development method. This research will develop a teaching material in the form of contextual-based physics modules which can later be used in the learning process and improve student physics learning outcomes. Teaching material developed using the ADDIE development model. The stages of this development model are: analysis, design, development, implementation, and feedback.

\section{Analyze}

Activities that can be carried out at this stage are analyzing the needs needed by researchers before the research takes place. Researchers can analyze the things that can be raised and determined as the basic problems faced in the physics learning process at school, so that from the existing problems can be given the right solution.

\section{Design}

At this design stage, researchers can write what are the main tasks that later must be mastered by students in order to achieve the objectives of the learning process. This stage will be needed to determine the contents of the learning unit. Researchers must be able to analyze the concepts that later need to be taught and incorporated into teaching materials to be developed. Researchers also write down achievements after the learning process. This stage is useful to limit researchers from deviating from the learning objectives to be achieved while writing teaching material to be developed. 
3. Development

At this stage of development the researcher must have made an initial product or design of the product to be developed. This stage is used to create modules that are tailored to the chart of the results of the analysis and design that has been done in the previous stage. This stage is also used to prepare the conceptual framework of the model and also the teaching material to be developed.

\section{Implementation}

Before the developed product is tested on students, the textbook must be validated first by the experts. This validating activity is used to assess the feasibility of the draft textbook to be developed. This activity is carried out by expert lecturers who are responsible for their respective fields. Suggestions from the validator can later be used to improve the teaching material. After going through the validation stage, the next step is to test the teaching material on the actual target subjects. At the time of the trial, responses, reactions and comments from the textbook users were searched. The results of this trial will be used to improve the textbook. After the textbook is finished being repaired, it is tested again until it gets effective results. In the implementation phase (implementation) is done by testing the content and readability of textbooks to experts involved in the product validation process. The results of the tests that have been carried out are then used as a reference in revising the product so that the teaching material developed actually meets the needs of its users.

\section{Evaluation}

The final stage of the ADDIE development model is evaluating. This evaluation stage is divided into 2 steps, namely formative evaluation and summative evaluation. However, in this development research, only the formative evaluation stage is carried out. Formative evaluation is used to see whether the product being developed is good or needs further improvement. In formative evaluation, students will later be given a matter of practice where the material is taken from textbooks developed. The exercise questions are used to see the level of effectiveness of the textbooks that have been developed.

\section{Population and Sample}

This research took a population of high, medium and low ability students who were scattered in the Lubuklinggau City Education Department. With the reason to choose the school to represent the entire number of high school level schools in Lubuklinggau. In this study, the subject of research when identifying the feasibility of teaching materials is class $\mathrm{X}$ students through purposive sampling techniques.

\section{Data Collection and Instrument}

At this stage of the study, the subject of this study were three validators, namely material, language and media validators. Data collection techniques used were questionnaires and documentation with quantitative descriptive analysis techniques. 


\section{Data Analysis}

The data collected was analyzed using quantitative descriptive methods to determine module eligibility. The physics module with this pyrolysis tool is validated by material experts on three indicators, namely: 1) the scope of the material; 2) material accuracy; and 3) inquiry, because this physics module is based on inquiry approach. (Sugiyono, 2016) states that the score that has been set can be calculated as follows:

$$
\text { Percentage }=\frac{\text { score obtained }}{\text { maximum score }} \times 100 \%
$$

\section{RESULT AND DISCUSSION}

Development of teaching materials with pyrolysis tools is arranged into modules. Modules are validated by the validator in terms of material, language and media. This is done to determine the level of validity of teaching materials.

\section{Material Validation}

For selecting material validation questionnaires:

maximum score $: 12 \times 4=48$

Scale : 4

Range of Scores: $=\frac{\text { score obtained }}{\text { maximum score }}=\frac{48}{4}=12$

From the results of measurements made using a questionnaire, the percentage can be seen. The following table presents the percentage and range of scores for each questionnaire:

Table 1. Range of Evaluation Questionnaire Materi Validator

\begin{tabular}{ccc}
\hline Range of Scores & Percentage & Category \\
\hline $37-48$ & $77,08 \% \leq \mathrm{P}<100 \%$ & Very good \\
$25-36$ & $52,08 \% \leq \mathrm{P}<75 \%$ & Good \\
$13-24$ & $27,08 \% \leq \mathrm{P}<50 \%$ & Not good \\
$0-12$ & $0 \% \leq \mathrm{P}<25 \%$ & Very less \\
\hline
\end{tabular}

Continually the sum of all scores can be described as follows

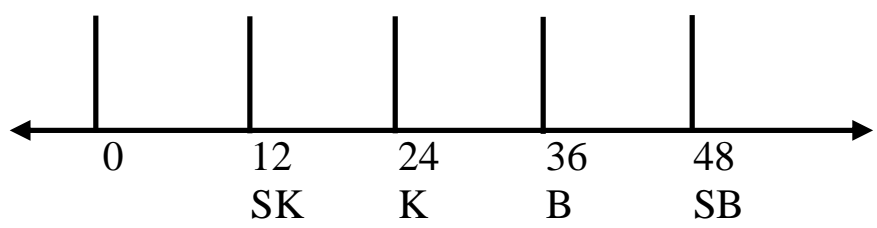


Table 2. Validation results of the material data

\begin{tabular}{cccc}
\hline Repetition & Material validation & Percentage \\
\hline 1 & & 38 & $79.16 \%$ \\
2 & 44 & $85.41 \%$ \\
3 & & - & - \\
Rating result & 82 & $82,23 \%$ \\
& Total & & Very good \\
\hline & Category &
\end{tabular}

The results of the analysis of the material expert validator questionnaire, the expert's response to the first validation of the material feasibility component was included in the good category with a percentage of $79.16 \%$. It was stated that the teaching materials were valid, but there were still comments from the validator to improve teaching materials before being trialled. The validator asks to perfect the formula with the material. The second validation, there are no validato comments and valid teaching materials are in the excellent category with a percentage of $85.41 \%$.

The following is an explanation of the material validation indications:

\section{1) Material Coverage}

The scope of material in the inquiry-based module which consists of the suitability of the material with Competency Standards (SK) and Basic Competence (KD) is fairly good and the concept and definition accuracy is also good.

\section{2) Material Accuracy}

The concepts and theories presented in this module do not cause many interpretations to mean the concepts and theories are in accordance with the material and can be used properly. Work procedures are presented in accordance with applicable, in the presentation, the method is coherent and rightly said to be good. As well as the theory presented in accordance with the material and the writing of the formula, clear and consistent written units are said to be good too. In research on this inquiry-based module the material has been adapted to concepts and theories and in the module there is already a phase of inquiry so students find it easier to understand the concepts and theories of existing material.

3) Inquiry

Inquiry-based physics module means that the contents of this module are the steps of inquiry syntax which include: the activity of giving stimulation to students to be able to find fairly good, activities that encourage students to investigate what students want to know can be said to be good, provide opportunities for students to giving good questions, activities that involve students to formulate problems with answers or conjectures that have not been examined for truth (formulating hypotheses) are said to be good, student activities to collect data or information both in practice and discussion to test the proposed hypothesis (collecting data) are categorized as good, activities to determine answers that are considered correct in accordance with the data or 
information obtained (testing hypotheses) are categorized as good, and students can make conclusions from the learning activities carried out fairly well.

\section{Language Validation}

The physics module is expected to have good readability and use appropriate language. This module is validatesd by an expert validator, a language and literature lecturer who is competent in the language field. Open questionnaire given to linguists is used to see the feasibility and get an evaluation of the linguistic component consisting of six aspects to be assessed including: 1) the letters used are simple and easy to read;2) the sentences and paragraphs used in this module are clear and easy to understand; 3 ) consistency in the use of terms and symbols / symbols; 4) accuracy of grammar and spelling; 5) linkages between sentences, between paragraphs and between concepts; and 6) completeness of supporting presentation (containing preface, table of contents, and bibliography).

For selecting material validation questionnaires:

maximum score $: 6 \times 4=24$

Scale : 4

Range of Scores: $=\frac{\text { score obtained }}{\text { maximum score }}=\frac{24}{4}=6$

The table below shows the percentage and range of scores for each questionnaire:

Table 3. Range of Evaluations for Language Validator Questionnaire

\begin{tabular}{ccc}
\hline Range of Scores & Percentage & Category \\
\hline $19-24$ & $79,2 \% \leq \mathrm{P}<100 \%$ & Very good \\
$13-18$ & $54,2 \% \leq \mathrm{P}<75 \%$ & Good \\
$7-12$ & $29,2 \% \leq \mathrm{P}<50 \%$ & Not good \\
$0-6$ & $0 \% \leq \mathrm{P}<25 \%$ & Very less \\
\hline
\end{tabular}

Continually the sum of all scores can be described as follows

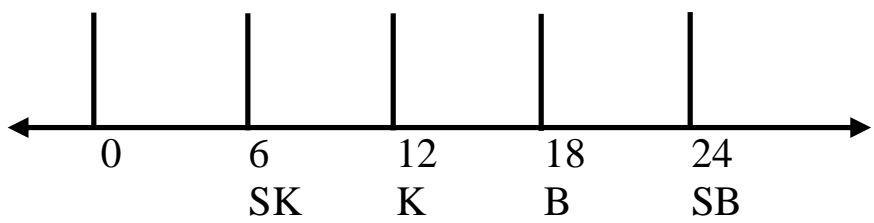

Table 4. Language validation results data

\begin{tabular}{cccc}
\hline Repetition & Language validation & Percentage \\
\hline 1 & & 18 & $75.00 \%$ \\
2 & 23 & $79.62 \%$ \\
3 & - & \\
Rating result & 41 & $77,31 \%$ \\
& Total & & Very good \\
\hline & Category & \\
\hline
\end{tabular}


The linguist validator stated that this teaching material was valid in the good category with a percentage of $75.00 \%$. Thus the language of the teaching material is valid, but there is input from the validator is the adjustment to the rules of the Indonesian language and the use of language that is easily understood. As for the second validation from linguists, it is declared valid in very good categories with a percentage of $79.62 \%$.

The following is a detailed explanation of the linguistic component:

1. Letters used are simple and easy to understand: Letters used are simple in either category by using Times New Roman letters that are considered easy to read.

2. Sentences and paragraphs used in this module are clear and easy to understand: in the inquiry-based module the sentences and paragraphs use the accuracy of sentence structure and the rigidity of the terms is fairly good because it has followed the writing of Enhanced Spelling (EYD).

3. Consistency of terms and symbols: consistency of terms and symbols in the inquiry-based module is stated as good, this is seen from the writing of the symbols used that are not changing from beginning to end.

4. Accuracy of grammar and spelling: Accuracy of grammar and spelling in inquiry-based modules in both categories by giving suggestions regarding errors in writing "in" as prepositions and prefixes in sentences.

5. The interrelationship between sentences, paragraphs and between concepts: the interrelationship between sentences, paragraphs and between concepts in the inquiry-based module in both categories which can be seen in each material interrelated.

6. Completeness of supporting presentation: completeness of supporting presentation such as: the presence of student identity, preface, table of contents, competency standards and basic competencies, module position map and bibliography on inquiry-based modules are fairly good.

\section{Media Validation}

The results of the inquiry-based module media validation were carried out on nine indicator items to evaluate the module design and the feasibility of presenting the physics module which included: 1) the suitability of the module size with the contents of the material; 2) the color of the elements of the harmonious layout and clarify the function of the physics module; 3) student centered and student involvement; 4) don't use too many letter combinations; 5) consistency of writing physical symbols; 6) intertwined interactive communication; 7) compatibility with material characteristics; 8) Balance between picture and writing illustrations; and 9) the relationship between facts and concepts.

For selecting media validation questionnaires:

maximum score $: 9 \times 4=36$

Scale : 4

Range of Scores: $=\frac{\text { score obtained }}{\text { maximum score }}=\frac{36}{4}=9$ 
Table 5. Range of Evaluation Questionnaire Media Validator

\begin{tabular}{ccc}
\hline Range of Scores & Percentage & Category \\
\hline $28-36$ & $77,7 \% \leq \mathrm{P}<100 \%$ & Very good \\
$19-27$ & $52,7 \% \leq \mathrm{P}<75 \%$ & Good \\
$10-18$ & $27,7 \% \leq \mathrm{P}<50 \%$ & Not good \\
$0-9$ & $0 \% \leq \mathrm{P}<25 \%$ & Very less \\
\hline
\end{tabular}

Continually the sum of all scores can be described as follows:

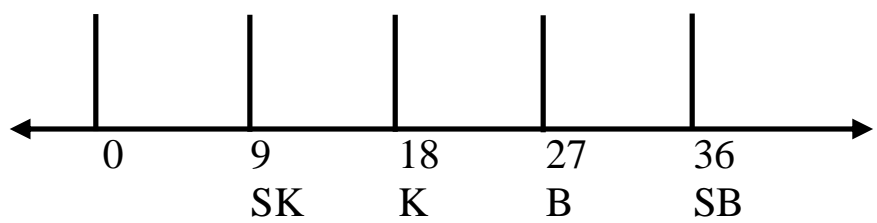

Table 6. Data validation results of the media

\begin{tabular}{cccc}
\hline Repetition & Validasi media & Percentage \\
\hline 1 & 26 & $72.22 \%$ \\
2 & 33 & $91.66 \%$ \\
3 & - & - \\
Rating result & 59 & $81,94 \%$ \\
& Total & & Very good \\
\hline & Category & \\
\hline
\end{tabular}

The media expert validator stated that this teaching material was categorized well with a percentage of $72.22 \%$. But there is a note from the validator in the first validation, which is the revision of the cover using language and writing layout, so it is necessary to do the second validation. The results of the validation of the two teaching materials are declared valid in the excellent category with a percentage of $91.66 \%$.

The following explanation is below:

1. Compatibility of module size with material content

The suitability of the module size with the contents of the material is the use of kestar and the size and who can adjust to the contents of the module material. This study chose to use a paper size of A4 because this paper was considered good and suitable to be used to adjust the material content in the module. The quality of the paper used in the inquiry-based module is good. The paper used on the front and back covers is different from the paper on the contents of the material. The front and back cover paper called the cover is chosen a little hard so that it looks like a real book, besides that the selection of paper on the cover is also slightly shiny so that the image produced in the inquiry-based module print is slightly better and can attract students to read the book.

2. Color the elements of the harmonious layout and clarify the function of the physics module

The color chosen shows the usefulness and function of the color to clarify the contents of the inquiry-based module very well. The researcher chooses a white 
background, but for the selection and use of colors is chosen based on the use to clarify the material's function in shapes. For example light pink is used to clarify the systematic formulation of the module contents.

3. Student centered and student involvement

The inquiry based physics module is good for focusing on students and student involvement, meaning that inquiry-based modules are designed to prioritize student involvement that will play an active role in exploring communication skills in expressing opinions and ideas by formulating problems, seeking answers and answering them by themselves and being independent both through pratikum or discussion.

4. Don't use too many letter combinations

Letters used in inquiry-based physics modules, $80 \%$ use letters with a new roman time setting with varying font sizes. And don't use too many riot combinations. So that in this category is said to be good. The quality of the module layout is good.

5. Consistency of writing symbols

Writing symbols on the physics module is fairly consistent, this is intended so that students easily understand the symbols that exist, can communicate well with the symbols on the module, and do not experience errors writing symbols in physics making it easier for children to learn symbols the physics of the inquiry-based module.

6. Interdependence of interactive communication

Communication is needed in learning physics not only in writing but reading skills to understand the contents of the book so that it can be understood and understood for students, therefore inquiry-based modules are designed to create intertwining between both students with modules, students with teachers and teachers with modules so students can apply business materials and energy well. The intertwining communication in the module is fairly good.

7. Conformity with material characteristics

Conformity with the characteristics of the material is good, meaning that the inquiry-based module is based on the characteristics of class $\mathrm{X}$ students who have just switched from the junior high school mass, in junior high school there are materials to assess effort and energy which are discussed in general while at the high school level there is the same material but specifically explained. Students are required to study independently and actively to be able to find solutions to the problems encountered.

8. Balance between picture illustration and writing

The balance of picture and writing illustrations is good. This means that the balance between picture illustrations and writing must be appropriate so that students easily understand what is meant.

9. Relationship between facts and concepts

The relationship between facts and concepts is very good, the intention is that between facts and concepts can support and strengthen each other in teaching and learning activities. Facts in the discussion of material, examples of questions, and exercises as outlined in the material in accordance with the 
concepts provided make it easier for children to think logically and can build their own knowledge.

\section{CONCLUSION}

The physics module of temperature and calor easible to use in terms of material, language and media validation. Results of expert responses on the first validation of the material eligibility component are valid in either category with a percentage of $79.16 \%$. The second validation is declared valid in the excellent category with a percentage of $85.41 \%$. The results of expert responses on the first validation of linguists with a good percentage of $75.00 \%$ categorized. As for the second validation from linguists, $79.62 \%$ of the category is very good. The response of the validator of the media experts on the validation of the percentage of $72.22 \%$ in the good category, the second validation of the percentage of $91.66 \%$ in the very good category.

\section{REFERENCES}

Majid, A. (2011). Perencanaan Pembelajaran Mengembangkan Standar Kompetensi Guru. PT.Remaja Rosdakarya.

Morelent, Y., dan S. (2015). Jurnal gramatika. 2, 141-152.

Prastowo, A. (2014). Pengembangan Bahan Ajar Tematik: Tinjauan Teoretis dan Praktik. Kencana.

Santi, N.W., Agus.S., dan E. . (2018). Pengembangan Buku Elektronik Inti Atom Sebagai Bahan Ajar Mandiri Untuk Menumbuhkan Kemampuan Berfikir Kritis Siswa. Jurnal Pembelajaran Fisika, 6(2), 134-145.

Setiani, E., Feriansyah S., dan I. D. P. . (2018). Pengembangan lembar kerja siswa berbasis predict-observe-explain (poe) pada materi fluida dinamis. Jurnal Pembelajaran Fisika, 6(2), 147-159.

Sugiyono. (2012). Statistika Untuk Penelitian. CV.Alfabeta.

Sugiyono. (2016). Metode Penelitian Pendidikan Pendidikan dan Pendekatan Kuantitatif, Kualitatif, dan R\&D. CV.Alfabeta.

Suwarni, E. (2015). Pengembangan Buku Ajar Berbasis Lokal Materi Keanekaragaman Laba-laba DI Kota Metro Sebagai Sumber Belajar Alternatif Biologi Untuk Siswa SMA Kelas X. BIOEDUKASI Jurnal Pendidikan Biologi Univesitas Muhammadiyah Metro, 6, 86-92. 